九州大学学術情報リポジトリ

Kyushu University Institutional Repository

\title{
Mass Production of Entomopathogenic Nematode, Heterorhabditits megidis by Using Micorosparger of Gandong Strain
}

Kim, Tae Wan

Central Research Institute, WooGene B\&G Co., Ltd

Aoki, Chisa

Laboratory of Insect Pathology and Microbial Control, Institute of Biological Control, Faculty of Agriculture, Kyushu University

Yasunaga, Chisa

Laboratory of Insect Pathology and Microbial Control, Institute of Biological Control, Faculty of Agriculture, Kyushu University

Yu, Yong Man

Departmentof Applied Biology, College of Agriculture and Life Sciences, Chungnam National University

https://doi.org/10.5109/1467630

出版情報：九州大学大学院農学研究院紀要. 59 (2)，pp. 283-288，2014-08-29. Faculty of Agriculture, Kyushu University

バージョン :

権利関係 : 


\title{
Mass Production of Entomopathogenic Nematode, Heterorhabditits megidis by Using Micorosparger of Gandong Strain
}

\author{
Tae Wan KIM ${ }^{1}$, Tae Hwan KIM ${ }^{1}$, Chisa YASUNAGA-AOKI ${ }^{2 *}$ \\ and Yong Man $\mathbf{Y U}^{3 *}$ \\ Laboratory of Insect Pathology and Microbial Control, Institute of Biological Control, \\ Faculty of Agriculture, Kyushu University, Fukuoka 812-8581, Japan \\ (Received April 25, 2014 and accepted May 12, 2014)
}

\begin{abstract}
In this study, the effects of microsparger on oxygen transfer velocity caused by micro aeration and reproduction of Heterorhabditis megidis in the process of using microsparger for mass culture production of entomopathogenic nematodes, Heterorhabditis megidis were examined. When ringsparger and microsparger were used in the incubator, changes in oxygen transfer coefficients $\left(\mathrm{K}_{\mathrm{L}} \mathrm{a}\right)$ were measured. It tended to significantly increase when microsparger with small pore size was used. It seemed to be caused by increase in the contact area between air bubbles and media. On the other hand, in the case of microsparger, the $\mathrm{K}_{\mathrm{L}} \mathrm{a}$ value was not increased, but it tended to be decreased when pore size got smaller despite the increase in aeration rate and stirring rate. In addition, Oxygen Uptake Rate (OUR) of Heterorhabditis megidis was $0.63 \times 10^{-2} \mathrm{mmol} \mathrm{O}_{2} / \mathrm{L} \cdot \mathrm{min}$ at appropriate incubation temperature of around $25^{\circ} \mathrm{C}$, and it tended to rapidly increase. While being cultured, the number of the optimal inoculated bacteria in 4,000 showed the highest yield of $300 \times 10^{3}$. On the $9^{\text {th }}$ day of incubation, the final yield of 3 stage IJ per $\mathrm{ml}$ was $400 \times 10^{3} .25 \mu \mathrm{m}$ microspargerwas attached to the incubator with capacity of 31 and Heterorhabditis megidis was cultured. As the result, Heterorhabditis megidisgrew with a high yield only when dissolved oxygen concentration fell below $20 \%$ and it was ventilated rather than continuous aeration.
\end{abstract}

Key words: Heterorhabditis megidis reproduction effects, microsparger, Oxygen transfer coefficients $\left(\mathrm{K}_{\mathrm{L}} \mathrm{a}\right)$

\section{INTRODUCTION}

Entomopathogenic nematodes belong to Rhabditida of Sececernentea and symbiotic bacteria reside in their intestine. If they break into the larvae of the insects and secrete toxic substance into hemolymph, the insects which are hosts will be killed within 24-48 hours.

Bacteria of Xenorhabdus and Photorhabdus, which are symbiotic bacteria are Gram negative bacteria with motility and they belong to enteric bacteria (Akhurst, 1980). These bacteria represent symbiotic life cycles of genuses of Steinernematidae and Heterorhabditdae which are entomopathogenic nematodes (Kaya and Gaugler, 1993). These nematodes have a different developmental origin, but the parasitic life cycles which they show are thought to show a similar pattern through the convergent evolution process (Adams and Nguyen, 2002). Bovien (1937) discovered symbiotic bacteria from DJ (dauer juvenile) of Steinernema felitiae for the first time. Poinar and Thomas (1966) described the importance of bacteria of Xenorhabdus nematophilus for reproduction of Steinernema carpocapsae. If infective nematodes with motility find the host, they get into the body through the opening part of the insects. After that,

\footnotetext{
Central Research Institute, WooGene B\&G Co., Ltd., \#528-5, Songasn-Ri, Yanggam-Myeon, Hwaseong-Si, Gyeonggi-Do 445-930, Korea

2 Laboratory of Insect Pathology and Microbial Control, Institute of Biological Control, Faculty of Agriculture, Kyushu University Dept. Applied Biology, College of Agriculture and Life Sciences, chungnam National University, Daejon 305-764, Korea

* Joint corresponding authors (E-mail: ymyu@cnu.ac.kr; yasunaga@grt.kyushu-u.ac.jp)
}

they penetrate the epidermal cell layer and break into the hemolymph. Infective nematodes which invade into the hemolymph send their specific enteric symbiotic bacteria (Xenorhadbus for Steinernematidae and Photorhabdus for Heterorhabditidae) to the hemolymph of insects (Forst et al., 1997). Bacteria coming out to the hemolymph play a role to suppress the immune response of insects in order to protect themselves and nematodes which are host for bacteria (Park and Kim, 2000).

On the other hands, infected insects induce the cellular and humoral immune actions in order to protect themselves from pathogenic bacteria and nematodes. Immune response of insects recognizes the foreign invader by pattern recognition proteins and this recognition information is delivered to the surroundings by using eicosanoids. Through this process, the immune response will be induced systematically (Gillespie et al., 1997). Both Xenorhabdus and Photorhabdus genuses which are symbiotic bacteria can suppress the immune response of insects. It could be caused by that the bacteria can inhibit the biosynthesis of eicosanoids in insects (Kim, 2009). However, since toxic protein of bacteria is unstable for the use of insecticides for symbiotic bacteria except entomopathogenic nematodes, the use is limited. Thus, entomopathogenic nematodes are cultured and used as the biological insecticides. Historically, in vitro mass culture production of Steinernema glaseri was attempted for prevention of Popillia japonica for the first time in the USA. However, it was failed, because they did not know the presence of symbiosis of symbiotic bacteria (Glaser, 1931). However, mass production is available now and they can be stored for a long time. 
In addition, effective penetration into the habitats of pests in which it was difficult for microorganisms to penetrate is available. With such advantages, it is being used as the biological insecticides in the world (Park and Kim, 1997).

The important first attempt for mass culture production was made by Bedding (1984). He obtained the solid culture technology by using Polyether-polyurethane sponge containing culture media for Steinernema spp. for production. In addition, liquid culture for entomopathogenic nematodes was attempted by Stoll (1952) for the first time. He cultured them in the shaker by using liver extracts as the liquid media. The reproducibility was approximately $400 \mathrm{DJ} / \mathrm{ml}$. At the time, Stoll found that it was productive in the culture process at the culture temperature of $21-25^{\circ} \mathrm{C}$ and $\mathrm{pH}$ of $6.0-6.5$, and he had an important observation in which it was more reproductive in the dark. Buecher and Hansen (1971) examined the effects of quantity of air flow and shear stress on the growth of entomopathogenic nematodes after the air was supplied to the liquid culture media. It opened the door to liquid mass production of entomopathogenic nematodes and provided the basic data for scaled up cultures.

Pace et al. (1986) attached the Flat-blade impeller to the10 $\mathrm{l}$ Bioreactor (Braun Biostat E) and then inoculated Xenorhabdus nematophilus. After they were incubated for 24 hours, he re-inoculated Steinernema carpocapsae 2,000 DJ/ml. They were incubated for 10 days while oxygen saturation of $20 \%$ was maintained at $23-28^{\circ} \mathrm{C}, 180 \mathrm{rpm}$. Entomopathogenic nematodes were reproduced in 40,000 DJ/ml. The first company which commercialized the liquid culture methods for entomopathogenic nematodes was Biosys (Palo Alto, Calif). They made mass production of Steinernema carpocapsae in large scale of 80,000 l in 1992. Currently, E-Nema GmbH (www.e-nema.de), Koppert B.V. (www.koppert. nl) and Microbio Ltd. (www.microbio-group.com) are doing mass production in Europe. However, it still has some problems such as low yield of nematodes and high production expense. The first domestic company which attempted the liquid culture was Bicosys (Korea). They were equipped with production facilities in 10,000 l for entomopathogenic nematodes, but they finally went out of business (2010) due to low yield and very low success rate of culture. In Korea, only WooGene B\&G (www.woogenebng.com) is currently producing the mass culture of entomopathogenic nematodes. Among these entomopathogenic nematodes, Steinernematidae and Heterorhabditidae species are being used in the market as the biological insecticides.

In this study, we performed the study on direct aeration method using microsparger with pore size in less than $100 \mu \mathrm{m}$ in the bioreactor for mass production of entomopathogenic nematodes on survival rate and increase in production yield of nematodes.

\section{MATERIALS AND METHODS}

genic nematodes used in this study were collected in the Gandong district in Gangwon Province and inoculated to aged larvae of Galleria mellonella. Entomopathogenic nematodes used in this study were determined by the phylogenetic analysis through identification of symbiotic bacteria by using 16S rRNA gene PCR. In this study, propagated 3 stage IJ nematodes were collected by using the White trap and stored in the refrigerator at $10^{\circ} \mathrm{C}$. The number of nematodes used in this study was Heterorhabditis megidis 4,000/ml.

\section{Composition for culture media}

Composition of media used for mass culture production is as follows : Peptone $45 \mathrm{~g}$, whole milk powder $30 \mathrm{~g}$, sodium chloride $(\mathrm{NaCl}) 13 \mathrm{~g}$, potassium phosphate $\left(\mathrm{KH}_{2} \mathrm{PO}_{4}\right) 7.5 \mathrm{~g}$, yolkpowder $7.5 \mathrm{~g}$, yeast $3 \mathrm{~g}$, cholesterol $0.15 \mathrm{~g}$, soybean oil $150 \mathrm{~g}$, lecithin $1.5 \mathrm{~g}$ and lard $15 \mathrm{~g}$. After they were dissolved in triple distilled water and sterilized, they were used.

\section{Manufacture of a model nematode reactor and establishment of system for the measurement of DO}

For a reactor, a $7 \mathrm{l}$ glass cylindrical nematode reactor with the external diameter of $15 \mathrm{~cm}$, inner diameter of $13 \mathrm{~cm}$, thickness of $1 \mathrm{~cm}$ and height of $36 \mathrm{~cm}$ was manufactured by CNS Co., Ltd. For impeller attached to the inner diameter, a Paddle impeller with two wings was used. In the case of a Paddle Impeller, the diameter was $6 \mathrm{~cm}$ and the height was $10 \mathrm{~cm}$. The distance between lower impeller and the floor was $13 \mathrm{~cm}$ (Fig. 1). For the aeration device, removable ringsparger (SUS316L) and microsparger (Mott corporation) with aeration hole size of $24 \mu \mathrm{m}$ in external diameter of $1 \mathrm{~mm}$, inner diameter of $0.7 \mathrm{~mm}$ and length of $5 \mathrm{~cm}$ were used. Do probe (Broadley James: USA) was attached to above nematode incubator and data of output signals sent from probe were automatically stored every 5 seconds in the computer. Voltage delivered to the computer was converted into dissolved oxygen concentration (\%) by the equation and it was displayed on the screen.

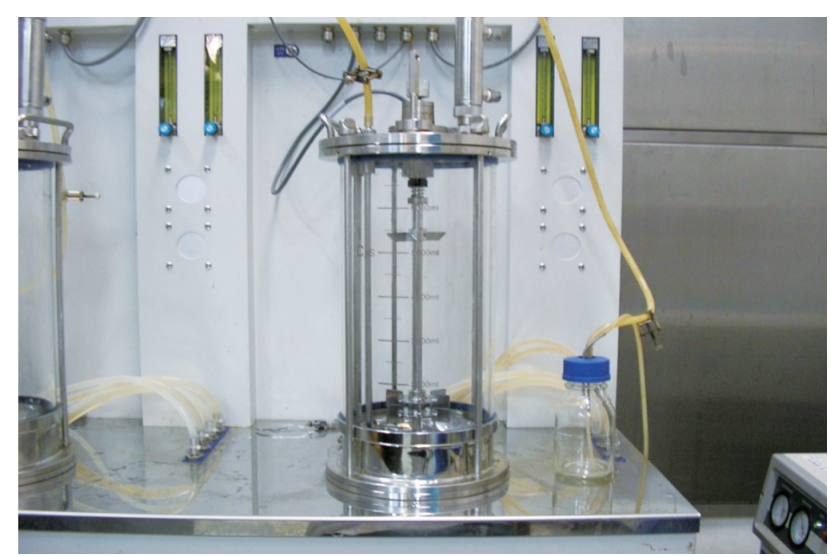

Fig. 1. Nematode Reactor model used in this study.

\section{Entomopathogenic nematodes}

Heterorhabditis megidis which were entomopatho- 


\section{Calculation of oxygen transfer coefficient $\left(K_{L} a\right)$}

In order to calculate the oxygen transfer coefficient $\left(\mathrm{K}_{\mathrm{L}} \mathrm{a}\right)$, we used dynamic method which was widely used in general (Jonson et al., 1990).

\section{Culture of entomopathogenic nematodes based on the size of air bubbles upon aeration in the reactor}

In order to examine the growth of nematodes and the yield based on size of air bubbles in the culture of Heterorhabditis megidis, a 71 Glass Cylindrical Vessel produced by CNS Co., Ltd. containing 31 of media in the working volume was maintained at the culture temperature of $25^{\circ} \mathrm{C}$. For nematodes, 3 stage IJ propagated by in vivo method in larvae of Galleria mellonella was inoculated at 4,000/ml. At the time, for Spager, ringsparger (aeration hole size: $1 \mathrm{~mm}$ ) and microsparger (aeration hole size: $24 \mu \mathrm{m}$ ) were attached (Figs. 2). In order to supply oxygen to the culture media, air was supplied through sparger attached to the bottom of vessel. In order to prevent the generation of excessive foams in the vessel during the aeration, antifoam LS-303 (Korea Dow Corning) was added from $0.005 \%$ to $0.01 \%$ based on the condition. After they were incubated at the agitation speed of $200 \mathrm{rpm}$ and by controlling the aeration rate for 10 days, the yield of nematodes was compared.

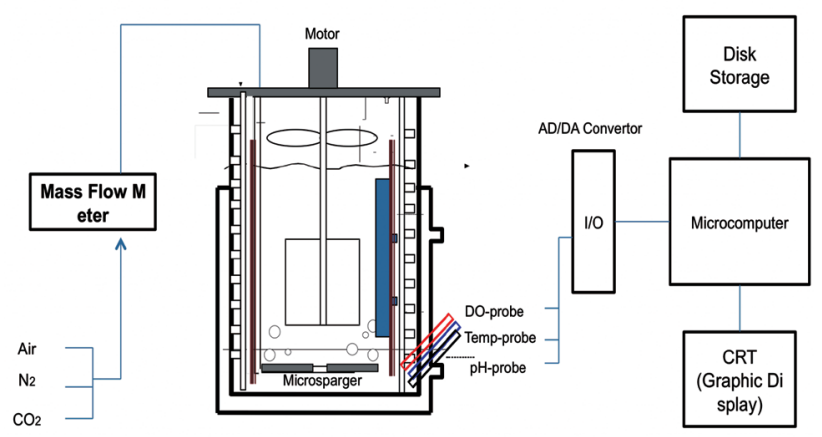

Fig. 2. Schematic diagram of System for Measurement of $K_{L} a$

\section{Measurement of oxygen uptake rate (OUR) of Heterorhabditis megidis}

For measurement of oxygen uptake rate (OUR) of Heterorhabditis megidis, a 7 l Glass Cylindrical Vessel was used. Three 1 of distilled water was poured into a $7 \mathrm{l}$ Glass Cylindrical Vessel and dissolved oxygen was maintained at $100 \%$ by supplying air while stirring it continuously at $100 \mathrm{rpm}$. In addition, after inoculating 3 stage IJ nematodes, air supply was stopped and the oxygen uptake rate (OUR) was measured. In addition, oxygen uptake rate (OUR) was measured at various temperatures ranging from $10^{\circ} \mathrm{C}$ to $30^{\circ} \mathrm{C}$ by every $5^{\circ} \mathrm{C}$. After agitation speed was changed at 50,100, 150, 200, 250 and $300 \mathrm{rpm}$, oxygen uptake rate (OUR) was measured.

\section{Measurement of $\mathrm{CO}_{2}$ in a reactor}

As Heterorhabditis megidis is growing, the amount of carbon dioxide produced in the incubator was meas- ured. At the time, the silicon tube was attached to the condenser where air of the upper part of a $7 \mathrm{l}$ Glass Cylindrical Vessel is vented, and it was connected to TOA EXHAUST $\mathrm{CO}_{2}$ Meter to measure $\mathrm{CO}_{2}$.

\section{RESULTS AND DISCUSSION}

\section{Effect of aeration hole size on the oxygen transfer rate}

Since it gives a very big economic burden to use entomopathogenic nematodes as a biological insecticide, the use is limited and the propagation based on mass culture production which is very important as the economic value is required. However, in order to make mass culture production of entomopathogenic nematodes as the commercialized biological insecticide, liquid culture method using a biological reactor is needed. Like an incubator of general aerobic microorganism, it is important to maintain oxygen transfer rate higher than oxygen uptake rate for nematode culture at high concentration. However, because oxygen has very low solubility in water (6-8 ppm) and nematodes are very sensitive to the shear rate, there is limitation to increase the agitation rate in a bioreactor in order to increase overall oxygen transfer coefficient (Kim and Park, 1998). In addition, oxygen uptake rate significantly varies based on life cycles of nematodes, and the oxygen supply is maintained at $5 \mathrm{mmol} / \mathrm{hr}$ during the culture of larvae. Oxygen should be supplied at up to $20 \mathrm{mmol} / \mathrm{hr}$ when they are propagated as the adult or female adults lay eggs (Friedman et al., 1991). In other words, we need to resolve or minimize above problems for mass culture production of nematodes. When a reactor for nematodes is designed, a small shear stress, high mixing capacity, optimal oxygen delivery system and possibility of scale-up should be considered as important conditions.

Oxygen transfer rate is mainly proportional to the agitation rate, aeration rate, and surface area of gas in contact with liquid per unit volume. When the air is supplied by using water and culture media with ringsparger in the reactor or water is used as media, oxygen transfer coefficient $\left(\mathrm{K}_{\mathrm{L}} \mathrm{a}\right)$ is $5-10 \mathrm{~h}^{-1}$. When the culture media is used as media, the oxygen transfer coefficient $\left(\mathrm{K}_{\mathrm{L}} \mathrm{a}\right)$ is $5-20 \mathrm{~h}^{-1}$. When water and culture media are used with Microsparger, the oxygen transfer coefficient $\left(\mathrm{K}_{\mathrm{L}} \mathrm{a}\right)$ is measured. When water is used as media, it is $5-30 \mathrm{~h}^{-1}$. When culture media is used as media, it is $5-60 \mathrm{~h}^{-1}$, which is higher. It seems to be caused by the increase in oxygen transfer, because the phenomenon is alleviated by media ingredients in which air bubbles are condensed in sparger when oxygen is supplied. In addition, according to the results of measurement, $\mathrm{K}_{\mathrm{L}} \mathrm{a}$ is bigger in microsparger which has small pore size of sparger than that in ringsparger. When both water and culture media are used, the same tendency is shown. It might be caused by bigger surface area, because relatively smaller air bubbles are produced when pore size gets smaller. In the case of ringsparger, $\mathrm{K}_{\mathrm{L}} \mathrm{a}$ is observed to increase constantly when the agitation rate and the aeration rate are increased. However, in the case of microsparger, $\mathrm{K}_{\mathrm{L}} \mathrm{a}$ does 


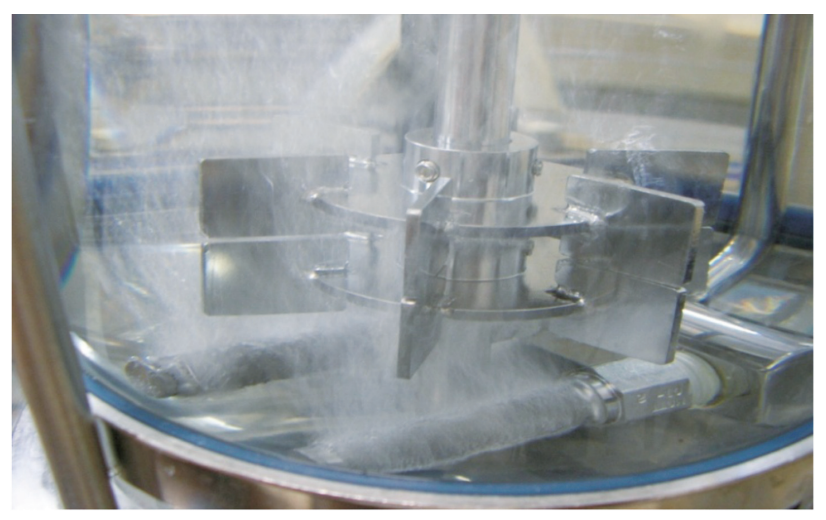

Fig. 3. Microsparger attached to a Nematode Reactor model.

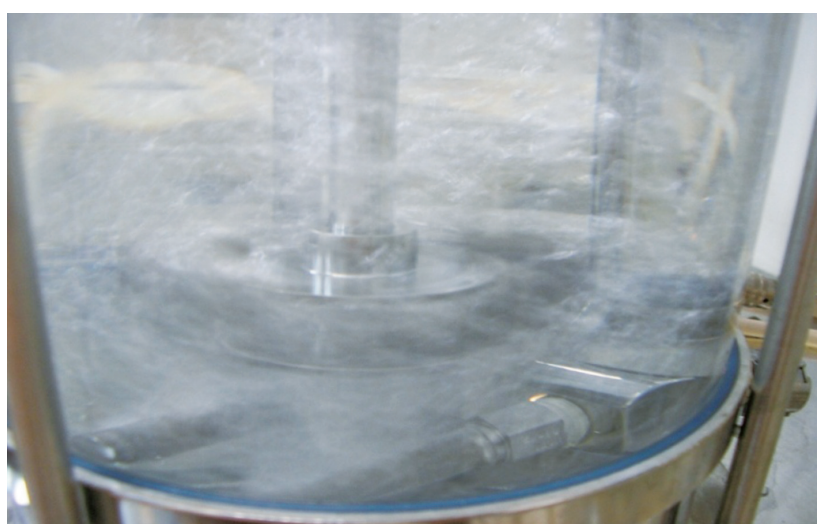

Fig. 4. Agglomeration of air bubbles by stirring.
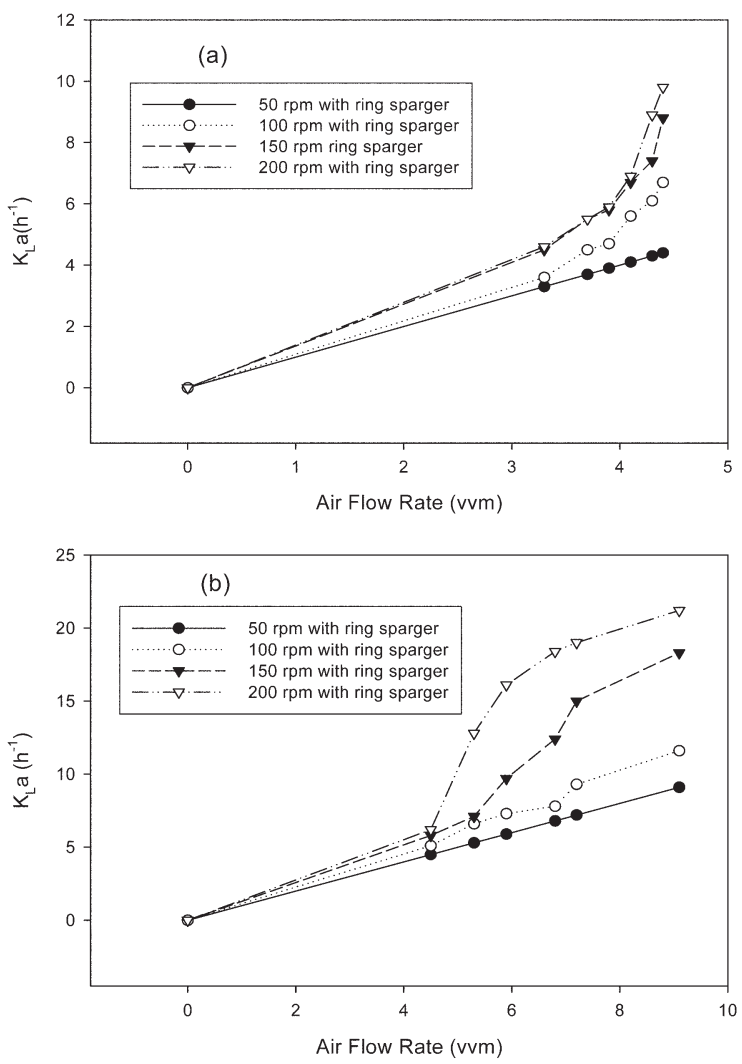

Fig. 5. Effects of agitation and aeration rates on $\mathrm{K}_{\mathrm{L}} \mathrm{a}$ in bioreactor with ringsparger.

Solute: water (a), medium (b) not tend to constantly increase with increasing agitation rate when culture media is used as the media. In high aeration rate, $\mathrm{K}_{\mathrm{L}}$ a is not increased with increasing agitation rate. It is confirmed that small air bubbles are condensed at the axis of rotation rather than increase of oxygen transfer by agitation when agitation rate is increased and they affect the oxygen transfer (Figs. 3, 4 and 5).

Oxygen uptake rates of Heterorhabditis megidis Gandong strain based on different temperature of 10, 15, 20,25 and $30^{\circ} \mathrm{C}$ and microsparger at agitation speed of $50 \mathrm{rpm}$ were measured. As the result, OUR at 10 and $15^{\circ} \mathrm{C}$
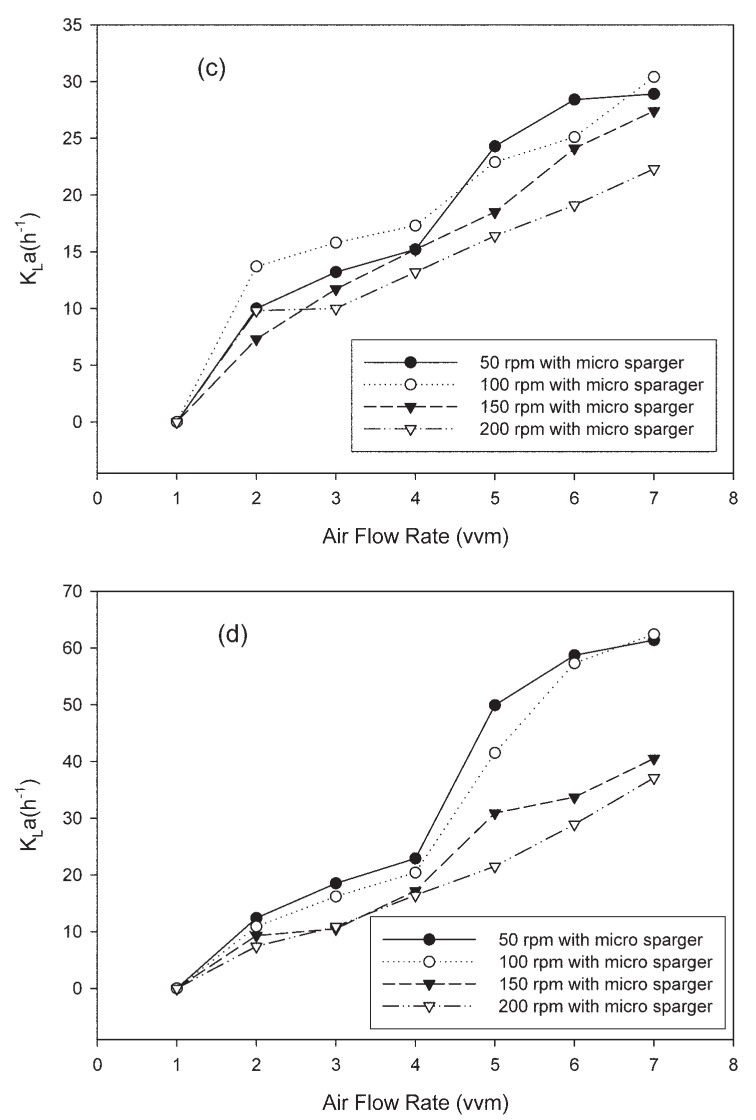

Fig. 6. Effects of agitation and aeration rates on $\mathrm{K}_{\mathrm{L}} \mathrm{a}$ in bioreactor with microsparger.

Solute: water (a), medium (b).

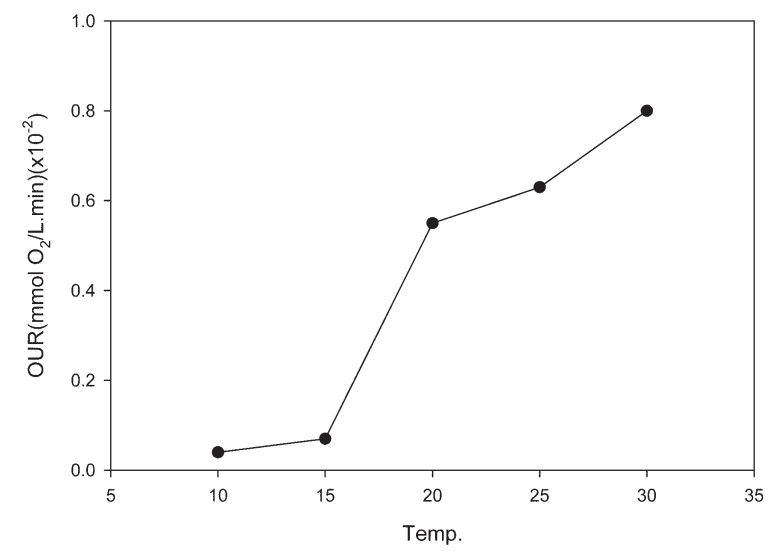

Fig. 7. Effect of temperature on oxygen uptake rate of nematodes (Heterorhabditis megidis Gandong strain). 
was $0.7 \times 10^{-3} \mathrm{mmol} \mathrm{O}_{2} / \mathrm{L} \cdot$ min which was relatively constant. However, OUR began to increase rapidly at $20^{\circ} \mathrm{C}$ and it was $0.63 \times 10^{-2} \mathrm{mmol} \mathrm{O}_{2} / \mathrm{L} \cdot \min$ at around $25^{\circ} \mathrm{C}$ which was the optimal temperature for culture. It was increased to $0.8 \times 10^{-2} \mathrm{~m} \mathrm{~mol} \mathrm{O}_{2} / \mathrm{L} \cdot \min$ at $30^{\circ} \mathrm{C}$ (Fig. 6).

\section{Culture yield based on counts of inoculated Heterorhabditits megidis Gandong strain}

The final culture yield based on counts of inoculated Heterorhabditits megidis Gandong strain was measured. As the result, the highest yield of $300 \times 10^{3} / \mathrm{ml}$ was shown when $4,000 / \mathrm{ml}$ was inoculated. When $5,000 / \mathrm{ml}$ was inoculated, the yield was lowered to $200 \times 10^{3} / \mathrm{ml}$ (Fig. 7).

\section{Culture yield based on using the microsparger with Heterorhabditits megidis Gandong strain}

Based on above results, we used the microsparger and agitation speed of $100 \mathrm{rpm}$. Amount of aeration was constant speed of approximately $0.5 \mathrm{vvm}$ in the initial culture. The amount of aeration was increased up to $1 \mathrm{vvm}$, only when dissolved oxygen concentration fell below $20 \%$ in the incubator. Since dissolved oxygen concentration could not be maintained at $20 \%$ with this aeration speed after 72 hours, they were incubated with

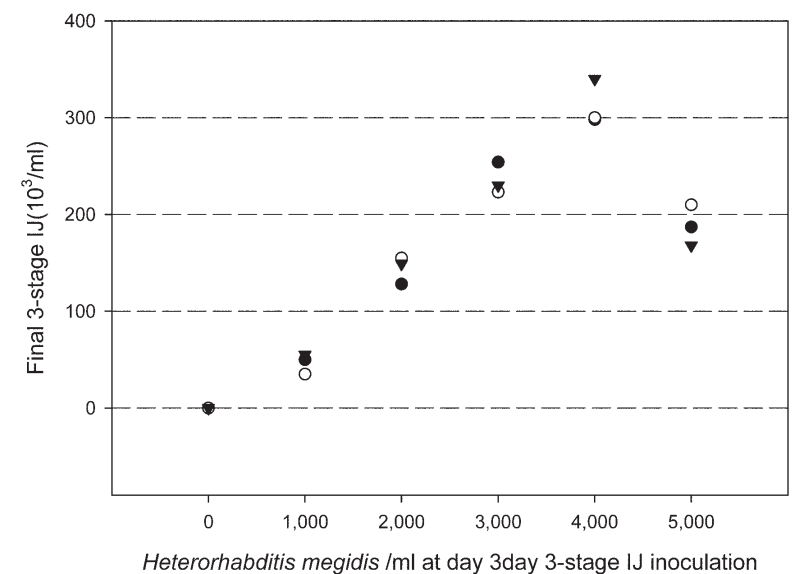

Fig. 8. Final 3-stage IJ yields/ml in relation to the density of Heterorhabditis megidis on day 3 after nematode inoculation.

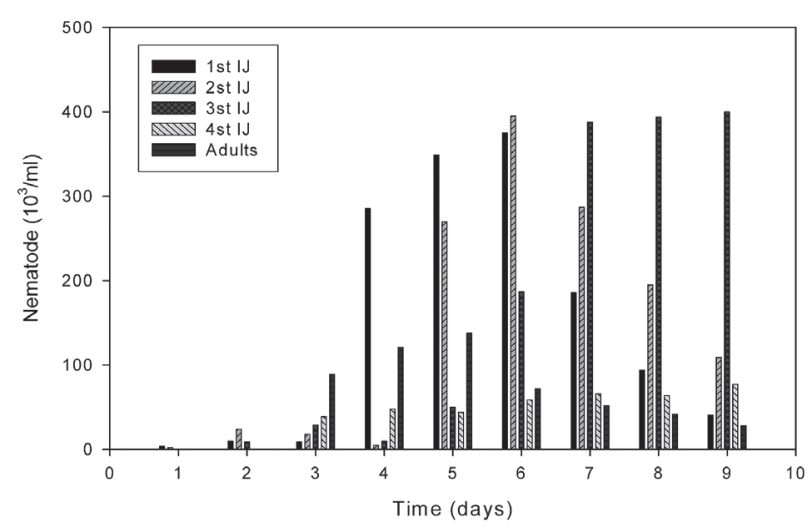

Fig. 9. Evolution of the population of Heterorhabditis megidis in culture.

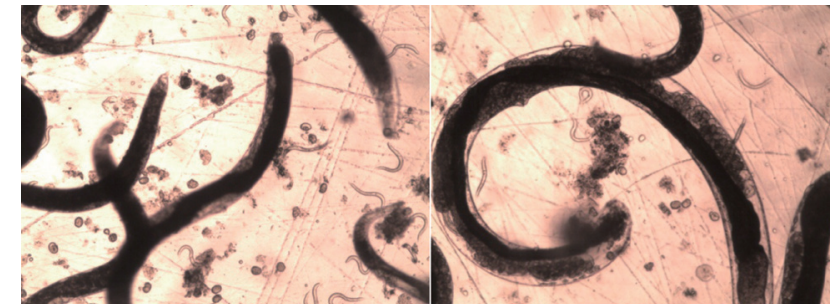

Fig. 10. 3-stage IJ form of nematode produced from cultured media.

increasing aeration speed by 0.1 in each step. The final culture yield of 3 stage $\mathrm{IJ} / \mathrm{ml}$ was $400 \times 10^{3}$ (Figs. 8). In the light of above results, when it is scaled up and mass culture production of entomopathogenic nematodes is made by using the direct aeration method with microsparger in the mass incubator, it is very important to intermittently supply oxygen when dissolved oxygen concentration falls below a certain level rather than continuous aeration. In particular, it was confirmed that the appropriate counts of inoculated bacteria for mass culture production was 4,000/ml (Fig. 9 and 10)

\section{ACKNOWLEDGEMENTS}

This study was supported by the project "Control Techniques of Lepidopteran Insect Pests Using Insect Pathogenic Bacteria (Project No.: PJ0100292014)" of the Rural Development Administration.

\section{REFERENCES}

Adams, B. J. and K. B. Nguyen 2002 Taxonomy and systematic. In "Entomopathogenic nematology", ed., by R, Gaugler, CABI Publishing, New York, pp. 1-33

Akhurst, R. J. 1980 Morphological and functional dimorphism in Xenorhabdus spp., bacteria symbiotically associated with the insect pathogenic nematodes Neoaplectana and Heterorhabditis. J. Gen. Microbiol., 121: 303-309

Bedding, R. A. 1984 Large scale production, storage and transport of the insect parasitic nematodes. Ann. Biol., 104:117-120

Bovien, P. 1937 Some types of association between nematodes and insects. Vidensk. Medd. Dansk. Naturhist. Foren., 101: 1-11

Buecher, E. J. and E. L. Hansen 1971 Mass culture of axenic nematods using continuous aeration. J. Nematol., 3: 199-200

Friedman M. J., S. E. Langston and S. Pollitt 1991 Mass production in liquid culture of insect killing nematodes. US Patent 5.023 .183

Forst, S. B., N. Dedos and E. Stackebrandt, 1997 Xenorhabdus and Photorhabdus spp. bugs that kill bugs. Annu.Rev. Microbiol., 51: 47-72

Gillespie, J. P., M. R. Kanost and T. Trenczek 1997 Biological mediators of insect immunity. Annu. Rev. Entomol., 42: 611643

Glaser, R. W. 1931 The cultivation of a nematode parasite of an insect. Science, 73: 614-615

Jonson, M., G. Andre, D. Dhavarie and J. Archambault 1990 Oxygen transfer rates in a mammalian cell culture bioreactor equipped with a cell-lift impeller. Biotechnol. Bioneg., 35 43-49

Kim, D. W. and S. H. Park 1998 Culture condition of entomopathogenic nematodes using Galleria mellonella larva. Korean J. Biotechnol. Bioeng., 13: 31-37

Kim, J. 2009 Research trend in biopesticide development. www. bioin.co.kr 
Kaya, H. K. and R. Gaugler 1993 Entomopathogenic nematodes. Ann. Rev. Entomol., 38: 181-206

Park, Y. and Y. Kim 2000 Eicosanoids rescue Spodoptera exigua infected with Xenorhabdus nematophila, the symbiotic bacteria to the entomopathogenic nematode Steinernema carpocapsae. J. Insect Physiol., 46: 1469-1476

Pace, G. W., D. E. Grote and M. Pitt 1986 Liquid culture of nematodes. Int. Patent WO 86/01074.

Park, S. H. and D. W. Kim 1997 Environmentally friendly biopesticide using entomopathogenic nematodes. Korean $J$.
Biotechnol. Bioeng., 12: 261-268

Stoll, N. R. 1952 Axenic cultivation of the parasitic nematode, Neoaplectana glaseri, in afluid medium containing raw liver extract. J. Parasitol., 39: 422-444

Poinar, G. O. Jr. and Thomas G. M. Thomas 1966 Significance of Achromobacter nematophilus Poinar and Thomas (Achromobactereace: Eubacteriale), in the development of the nematode, DD-136 (Neoplectanta sp., Steinernematidae). Parasitology, 56: $385-388$ 